\title{
PRAWO AUTORSKIE CHIŃSKIEJ REPUBLIKI LUDOWEJ
}

Wielokrotnie można się spotkać z poglądem, jakoby sformułowanie „prawo własności intelektualnej w Chińskiej Republice Ludowej” stanowiło swoisty oksymoron. Stanowisko takie, rozpowszechniane w szczególności w publikacjach popularnonaukowych, jest uzasadniane wieloma argumentami, które są wspierane danymi statystycznymi. Wskazuje się, że jeszcze dekadę temu naruszenia praw własności intelektualnej „kosztowały europejskich przedsiębiorców jednego dolara na każde pięć, które zarobili"’.

Zastanawiając się nad przyczynami takich tendencji w Państwie Środka, za Leonardem Górnickim warto wyjaśnić, że jeszcze w XVII w. tamtejsza myśl o prawach indywidualnych jednostek pozostawała w sprzeczności z cesarską koncepcją dobra wspólnego, w oparciu o którą twory ludzkiego intelektu automatycznie przechodziły do ówczesnego odpowiednika domeny publicznej ${ }^{2}$. Co więcej, kopiowanie dzieł było zjawiskiem nacechowanym pozytywnie, kwalifikowano je jako przejaw uznania dla twórczości autora ${ }^{3}$.

Chińska Republika Ludowa (ChRL) - najprawdopodobniej z uwagi na podjęcie wzmożonej współpracy z zagranicznymi przedsiębiorcami i zetknięcie się z gospodarką kapitalistyczną ${ }^{4}$ - podejmuje jednak od dłuższego czasu wzmożone działania, aby sprostać światowym standardom praw własności intelektualnej, ukierunkowanym na ochronę partykularnych interesów. Potwierdza to zarówno rozwój ustawodawstwa w tym zakresie, jak i wzrost liczby spraw sądowych oraz wysokości ustalanych sądownie odszkodowań ${ }^{5}$. Wypracowano i wprowadzono

1 T. Janyst, Chińskie prawo - co warto wiedzieć, http://www.polska-azja.pl/t-janyst-chinskie-prawo---co-warto-wiedziec/ (dostęp: 26.04.2018).

2 L. Górnicki, Roźwój idei praw autorskich: od starošytności do II wojny śniatowej, Wrocław 2013, s. $42,280$.

3 M. Jankowska, Autor i prawo do autorstwa, Warszawa 2011, s. 41 i nn.

4 J.K. Fairbank, Historia Chin, Warszawa 2007, s. 378-390.

5 M. Dresden, Copyright Protection in China - It's Real, and It's Spectacular, 22.05.2017, China Law Blog, China Law for Business, https://www.chinalawblog.com/2017/05/copyright-protectionin-china-its-real-and-its-spectacular.html (dostęp: 26.04.2017); State Intellectual Property Office of the People's Republic of China, 2015 Intellectual Property Rights Protection in China, http://english. sipo.gov.cn/laws/whitepapers/201607/P020160721403876149335.pdf (dostęp: 26.04.2018). 
wiele instytucji prawnych w celu zapewnienia bezpieczeństwa obrotu oraz stworzenia dogodnych warunków lokalnym i zagranicznym podmiotom. Przedmiot owej wzmożonej legislacji stanowi również promujące rozwój twórczości i nauki prawo autorskie 6 .

Wspomniane działania dostosowujące w ChRL zostały podjęte w 1979 r., kiedy to podpisano porozumienie o stosunkach handlowych ze Stanami Zjednoczonymi Ameryki Północnej, zaś kontynuowane wraz z przystapieniem do Światowej Organizacji Własności Intelektualnej (World Intellectual Property Organization WIPO) w 1980 r. oraz podpisaniem w 1992 r. Konwencji berneńskiej o ochronie dzieł literackich i artystycznych ${ }^{7}$. Dnia 11 grudnia 2001 r. ChRL została członkiem Światowej Organizacji Handlu (World Trade Organization - WTO), zobowiązując się tym samym do przestrzegania Porozumienia w sprawie handlowych aspektów praw własności intelektualnej (Agreement on Trade-Related Aspects of Intellectual Property Rights - TRIPS), stanowiącego integralną część Porozumienia w sprawie utworzenia $\mathrm{WTO}^{8}$. Wskazane akty zapewniają minimum ochrony praw własności intelektualnej, w tym prawa autorskiego?.

Materię prawa autorskiego w ChRL reguluje aktualnie ustawa Prawo autorskie Chińskiej Republiki Ludowej (ang. Copyright Law of the People's Republic of China; chiń. Zhonghua Renmin Gongheguo Zhuzuoquanfa 中华人民共和国著作权法), przyjęte na XV sesji Stałego Komitetu VII Ogólnochińskiego Zgromadzenia Przedstawicieli Ludowych dnia 7 września 1990 r., zmienione po raz pierwszy zgodnie z decyzja XXIV sesji Stałego Komitetu IX Ogólnochińskiego Zgromadzenia Przedstawicieli Ludowych z dnia 27 września 2001 r., zmienione po raz drugi zgodnie z decyzją XIII sesji Stałego Komitetu XI Ogólnochińskiego Zgromadzenia Przedstawicieli Ludowych z dnia 26 lutego 2010 r. ${ }^{10}$ Ustawodawca objął zakresem regulacji w szczególności następujące zagadnienia: przedmiot ochrony, podmiot ochrony, działalność organizacji zbiorowego zarządzania, okres ochrony, obrót prawami autorskimi, naruszenia praw autorskich, roszczenia przysługujące podmiotom uprawnionym w związku z naruszeniami.

6 M. Kania, Materialnoprawne, procesowe i instytucjonalne aspekty ochrony prawa wtasności intelektualnej w Chinach, http://www.repozytorium.uni.wroc.pl/Content/42405/005.pdf (dostęp: 26.04.2018).

7 Konwencja berneńska o ochronie dzieł literackich i artystycznych z dnia 9 września 1886 r., przejrzana w Berlinie dnia 13 listopada 1908 r. i w Rzymie dnia 2 czerwca 1928 r.

8 Porozumienie z dnia 15 kwietnia 1994 r. ustanawiające światową organizację handlu wraz z załącznikiem 1C - Porozumieniem w sprawie handlowych aspektów praw własności intelektualnej.

9 M. Głuchowska-Wójcicka, Zmiany w prawie własności intelektualnej po praystapieniu Chin do WTO [w:] Chiny w oczach Polaków. Ksiega jubileuszowa z okazji 60-lecia nawiqzania stosunków dyplomatycznych miedsy Polska a Chińska Republike Ludowa, red. J. Włodarski, K. Zeidler, M. Burdelski, Gdańsk 2010, s. 565-579.

${ }_{10}$ W dalszej części artykułu odwołuję się do anglojęzycznej wersji Copyright Law of the People's Republic of China, przytaczając przepisy w tłumaczeniu własnym z angielskiego. 
Celem przybliżenia prawnoautorskich założeń chińskiego ustawodawcy warto przeanalizować przepisy ogólne wskazanej ustawy, tj. rozdział I prawa autorskiego ChRL. W nich bowiem zawarto podstawowe założenia związane z funkcjonowaniem tego systemu ochrony.

W myśl art. 1 prawa autorskiego ChRL, stanowiącego quasi-preambułę, ustawa została wprowadzona zgodnie z konstytucją w celu ochrony praw autorów w ich literackiej, artystycznej i naukowej działalności, ochrony praw pokrewnych prawa autorskiego, podsycania kreatywności i rozpowszechniania utworów, co przyczyni się do budowania socjalistycznej cywilizacji duchowej i materialnej oraz promocji rozwoju i rozkwitu socjalistycznej kultury i nauki. Podstawowym celem przyświecającym ustawodawcy jest więc stymulowanie działalności twórczej, z tym jednak zastrzeżeniem, że twórczość winna działać na rzecz wskazanych wartości socjalistycznych.

Chiński ustawodawca nie uzależnia prawnoautorskiej ochrony od publikacji dzieła, nadto w sposób szczegółowy reguluje aspekt podmiotowy ochrony. W myśl art. 2 prawa autorskiego ChRL dzieła obywateli chińskich, jednostek prawnych i innych organizacji, bez względu na to, czy są opublikowane, zostaja objęte ochrona praw autorskich zgodnie z ustawą. Dzieło osoby zagranicznej lub bezpaństwowca (autora), który cieszy się ochroną swych praw autorskich na mocy porozumienia zawartego między krajem swojej przynależności lub swojego stałego zamieszkania a ChRL albo jest chroniony na mocy międzynarodowych traktatów, do jakich oba kraje przystapiły, podlega ochronie praw autorskich zgodnie z ustawa. Jakiekolwiek dzieło osoby zagranicznej lub bezpaństwowca, które swa pierwszą publikację ma na terytorium ChRL, jest objęte ochroną praw autorskich zgodnie z ustawa. Jakiekolwiek dzieło autora pochodzącego z kraju, który nie zawarł porozumienia z ChRL lub nie przystąpił do międzynarodowego traktatu, do jakiego przystapiła ChRL, a także dzieło bezpaństwowca, które pierwszą publikację ma w kraju będącym stroną międzynarodowego traktatu, do którego ChRL także przystapiła lub mające publikację jednocześnie w kraju będącym członkiem takiego traktatu i w kraju niebędącym członkiem takiego traktatu, jest objęte ochrona praw autorskich na mocy ustawy.

Co warto zaznaczyć, prawnoautorska ochrona utworu aktywuje się już w momencie jego ustalenia, nie jest więc zależna od jakiejkolwiek rejestracji. Jest to zgodne $z$ automatycznym modelem ochrony przewidzianym w Konwencji berneńskiej o ochronie dzieł literackich i artystycznych. Nie oznacza to jednak, że w ChRL brak systemu rejestracji utworów, bowiem funkcjonuje on na zasadzie dobrowolności zgłoszeń ${ }^{11}$. W celu prowadzenia stosownego rejestru oraz postępowań rejestracyjnych utworzone zostało Chińskie Centrum Ochrony Praw Autorskich (Copyright

11 Copyright Protection in China. A Guide for the European SMEs, http://www.china-iprhelpdesk.eu/ sites/all/docs/publications/EN_Copyright_guide_Aug_2010.pdf (dostęp: 26.04.2018). 
Protection Center of China - CPCC) ${ }^{12}$. Wnioskowe postępowanie rejestracyjne kończy się wydaniem świadectwa rejestracji praw autorskich. Dokument ten ma istotna moc dowodowa. Stwarza bowiem domniemanie ${ }^{13}$ istnienia praw autorskich po stronie podmiotu, na którego rzecz został wydany ${ }^{14}$.

Ustawodawca $\mathrm{w}$ art. 1 prawa autorskiego ChRL jako przykłady działalności objętej ochroną wskazuje działalność literacką, artystyczną i naukową. Zakres ten został doprecyzowany poprzez wskazanie form utworów w art. 3 ustawy, zgodnie $\mathrm{z}$ którym dzieła wymieniane w niej obejmują utwory literackie, artystyczne, prace z zakresu nauk przyrodniczych, nauk ścisłych, inżynierii i techniki itp. Są to:

1) utwory pisemne,

2) utwory ustne,

3) utwory muzyczne, dramatyczne, quyi $i^{15}$, choreograficzne i akrobatyczne,

4) utwory z zakresu sztuk pięknych i architektury,

5) utwory fotograficzne,

6) utwory kinematograficzne i wytworzone metodami podobnymi do metod kinematograficznych,

7) rysunki techniczno-projektowe, utwory wzornictwa przemysłowego, mapy, szkice $i$ inne prace graficzne oraz modele,

8) oprogramowanie komputerowe,

9) inne utwory objęte przepisami odrębnymi i regulacjami administracyjnymi.

Zgodnie $\mathrm{z}$ art. 4 właściciele praw autorskich, egzekwując swoje prawa, nie moga naruszać konstytucji, prawa ani interesu publicznego. Państwo nadzoruje publikację utworów oraz zarządza ich publikacją i rozpowszechnianiem pod kątem zgodności z prawem.

W kolejnym przepisie ustanowiono przedmiotowe wyłaczenia spod ochrony prawnoautorskiej. Zgodnie bowiem z art. 5 ochroną nie są objęte:

1) ustawy, przepisy prawne, uchwały, decyzje i nakazy organów państwowych; inne dokumenty o charakterze prawnym, administracyjnym czy sądowym, a także ich oficjalne tłumaczenia,

2) wiadomości o sprawach bieżących,

3) kalendarze, tabele numeryczne, formularze powszechnego użytku i formuły.

Zgodnie z powszechnie przyjęta praktyką legislacyjną ustawodawca w przepisach ogólnych wskazuje te zagadnienia, do których przepisy danej ustawy się nie odnosza. Regulacji prawa autorskiego ChRL nie podlegają utwory folklorystyczne, których zasady ochrony w myśl z art. 6 zostały przez Radę Państwową unormowane odrębnie.

12 http://www.ccopyright.com.cn/cpcc (dostęp: 26.04.2018).

13 Przy czym jest to oczywiście domniemanie wzruszalne.

14 Copyright Protection in China...

15 Quyi to tradycyjna chińska forma sztuki performance. 
Ustawodawca zdecydował się na utworzenie w ChRL krajowych i lokalnych departamentów administracyjnych ds. prawa autorskiego. Zgodnie z art. 7 prawa autorskiego ChRL Departament Administracyjny ds. Prawa Autorskiego przy Radzie Państwowej jest odpowiedzialny za zarządzanie prawem autorskim w całym kraju, zaś Departament Administracyjny ds. Prawa Autorskiego funkcjonujący w ramach lokalnych rząów ludowych na szczeblu każdej prowincji, regionu autonomicznego bądź miasta wydzielonego podlegającego bezpośrednio rządowi centralnemu jest odpowiedzialny za administrowanie prawem autorskim w zakresie swej jurysdykcji.

Ostatnią kwestią uregulowaną w przepisach ogólnych omawianej ustawy, tj. w art. 8, jest działalność organizacji zbiorowego zarządzania prawami autorskimi, które upoważnione przez twórcę lub inny podmiot uprawniony w odniesieniu do danego utworu podejmuja działania celem swoistego kolektywnego zarządu prawami autorskimi. W zakresie swojej działalności podmioty te mogą występować z roszczeniami w imieniu właścicieli praw autorskich lub osób uprawnionych do korzyści z tytułu tych praw. Nadto moga jako strona zainteresowana uczestniczyć w sporach sądowych i działaniach arbitrażowych związanych z prawami autorskimi lub prawami pokrewnymi. Organizacje te działają na zasadach non-profit. Sposób ich powstania, ich prawa i obowiązki, zasady pobierania przez nie honorariów z tytułu licencji oraz podziału tych opłat, nadto nadzór i zarząd nad nimi ustawodawca oddelegował do ustanowienia przez Radę Państwowa.

Ciekawym zagadnieniem, które ustawodawca przewidział już poza przepisami ogólnymi prawa autorskiego ChRL, jest instytucja dozwolonego użytku, zgodnie z którą w pewnych przypadkach uzasadnionego lub osobistego korzystania z utworu nie będzie ono wymagało zawierania umów czy też uzyskiwania odpowiednich zezwoleń twórcy ${ }^{16}$. Wyliczenie 12 przypadków dozwolonego użytku zawiera art. 22, zgodnie z którym nie dochodzi do naruszenia praw autorskich w przypadku przytoczenia niewielkiej części utworu w artykule naukowym, tłumaczenia dzieła opublikowanego przez obywatela chińskiego, osobę prawną lub organizację, które to dzieło stworzone zostało w języku chińskim i jest tłumaczone na język mniejszości narodowej w celu publikacji i dystrybucji w kraju, fotografowania lub nagrywania utworu artystycznego znajdującego się w miejscu publicznym czy też korzystania do celów samodzielnej nauki lub badań naukowych. Mając na względzie powyższe, należy stwierdzić, że a contrario niedozwolonym użytkiem będzie korzystanie z utworu w innych okolicznościach niż przewidziane przez ustawodawcę, chyba że odbywa się ono na podstawie odpowiedniej umowy bądź zezwolenia twórcy ${ }^{17}$.

Ustawa rozróżnia autorskie prawa osobiste i majątkowe, jednak podział ten jest mało wyraźny, gdyż w art. 10 wymieniono te prawa w 17 punktach w sposób łączny, nie precyzując, które $z$ nich kwalifikuje się jako prawa osobiste, a które jako prawa

16 Copyright Protection in China...

17 Ibidem. 
majątkowe. Rozróżnienie to można jednak pośrednio zdekodować z części in fine omawianego przepisu, formułującej uprawnienie do obrotu prawami wskazanymi w pkt 5-17 tego przepisu, a odmawiającej takiego uprawnienia dla praw wskazanych w pkt 1-4.

Obrót prawami autorskimi w ChRL odbywa się na podstawie umowy o przeniesienie praw autorskich albo na podstawie umowy licencyjnej ${ }^{18}$. Ustawodawca przewidział nadto instytucję licencji ustawowej, która ma zastosowanie w konkretnych przypadkach $^{19}$, jednak nie będzie ona przedmiotem analizy niniejszego artykułu.

Zarówno umowa o przeniesienie praw autorskich, jak i umowa licencyjna zostały uregulowane w rozdziale III prawa autorskiego ChRL. Ustawodawca przewidział minimalną wymagalną treść obu wskazanych umów, zastrzegając jednocześnie, że winny one zawierać także inną treść, którą obie strony uznają za niezbędną. Godny uwagi jest art. 28, zgodnie z którym wysokość wynagrodzenia za korzystanie z utworu może zostać uzgodniona przez zainteresowane strony lub ustalona przez Departament Administracji Praw Autorskich w ramach Rady Państwowej we współpracy z innymi zainteresowanymi departamentami, który to podmiot bezwzględnie ustali wysokość wynagrodzenia w przypadku, gdy zainteresowane strony nie osiagną jednoznacznego porozumienia w tym zakresie.

Mając na uwadze omówiony podział na autorskie prawa osobiste i majątkowe, warto zaznaczyć, że zgodnie z art. 20-21 pierwsze z nich są nieograniczone w czasie, zaś drugie trwają co do zasady przez 50 lat po śmierci twórcy.

$\mathrm{Na}$ zakończenie należy zwrócić uwagę na specyfikę legislacyjną ChRL. Mamy bowiem do czynienia z jednej strony z prawem tworzonym na szczeblu ogólnokrajowym, zaś z drugiej strony z prawem tworzonym na szczeblu lokalnym. Ów podział występuje również na gruncie prawnoautorskim, tak więc w zależności od odpowiednio określonej właściwości miejscowej mogą występować odmienne uregulowania ${ }^{20}$.

Za Mają Głuchowską-Wójcicką warto skonstatować, że ChRL „przeszła długą drogę w kierunku nowoczesnego systemu ochrony własności intelektualnej i w obecnej chwili jest stroną większości najważniejszych międzynarodowych traktatów dotyczacych ochrony praw niematerialnych"21. Na przestrzeni lat powołano wiele publicznych instytucji działających w zakresie praw własności intelektualnej. Wypracowane rozwiązania ustawodawcze w pełni odpowiadaja założeniom przewidzianym w szczególności przez konwencję berneńską oraz TRIPS. Z pełnym

18 Należy zaznaczyć, że obrotem mogą zostać objęte wyłącznie autorskie prawa majątkowe. Autorskie prawa osobiste są niezbywalne, pozostają więc przy twórcy.

19 Copyright Protection in China...

20 United States International Trade Commission, China: Intellectual Property Infringement, Indigenous Innovation Policies, and Frameworks for Measuring the Effects on the U.S. Economy, Washington 2010, s. 30-40; M. Kania, Materialnoprawne, procesowe i instytucjonalne aspekty...

21 M. Głuchowska-Wójcicka, Zmiany w prawie własności..., s. 569. 
przekonaniem można więc stwierdzić, że z punktu widzenia stricte prawnego funkcjonujący w ChRL system prawa autorskiego odpowiada światowemu poziomowi.

\section{SUMMARY}

\section{COPYRIGHTS IN THE PEOPLE'S REPUBLIC OF CHINA}

The paper tackles basic information on the Copyright Law in the People's Republic of China. The discussed theme is particularly interesting because the concept of the protection of the rights of an individual remained for many years contradictory to the concept of common good rooted in the tradition of the Central State. However, since 1979, the Chinese legislature has taken a number of measures to adjust its national copyright regulations to international standards. The reached legislative solutions fully correspond to principles stipulated mainly in documents such as the Bern Convention and the TRIPS Agreement. Thus, it can now be said with full confidence that from the strictly legislative point of view, the copyright system binding in the People's Republic of China meets the global standards. 